\title{
Avaliação comportamental do processamento auditivo em indivíduos gagos***
}

\author{
Behavioral auditory processing evaluation in individuals with \\ stuttering
}

\author{
Adriana Neves de Andrade* \\ Daniela Gil** \\ Ana Maria Schiefer** \\ Liliane Desgualdo Pereira**
}

*Fonoaudióloga. Mestranda em Distúrbios da Comunicação Humana Campo Fonoaudiológico pela Universidade Federal de São Paulo. Endereço para correspondência:

Rua São Francisco, 498 - São Caetano do Sul - SP - CEP 09530-050 (adriandrad@hotmail.com).

**Fonoaudióloga. Doutora em Distúrbios da Comunicação Humana Campo Fonoaudiológico pela Universidade Federal de São Paulo. Professora Adjunto do Departamento de Fonoaudiologia da Universidade Federal de São Paulo.

***Trabalho Realizado no Ambulatório de Avaliação do Processamento Auditivo da Disciplina dos Distúrbios da Audição do Departamento de Fonoaudiologia da Universidade Federal de São Paulo.

Artigo Original de Pesquisa

Artigo Submetido a Avaliação por Pares

Conflito de Interesse: não

Recebido em 18.09.2006.

Revisado em 06.03.2007; 06.09.2007; 17.12.2007; 19.01.2008; 12.02.2008. Aceito para Publicação em 12.02.2008.

\begin{abstract}
Background: the behavioral auditory processing (AP) evaluation allows the investigation of neuroaudiological processes involved in speech fluency processing. Aim: the purpose of this study was to describe the results obtained in the AP evaluation in stutterers, comparing the type of AP disorder with the severity of stuttering. Method: 56 subjects, 49 male and 7 female, ranging in age from 4 to 34 years, were referred from the speech-language clinic of UNIFESP to the AP evaluation. All patients were submitted to the following evaluations: audiological, speech and language. Disfluency was classified according to the protocol proposed by Riley (1994) which includes the following stuttering severity levels: very mild, mild, moderate, severe and very severe. Behavioral AP tests were selected and analyzed according to the patient's age and to the proposal of Pereira \& Schochat (1997). Results: subjects with ages between 4 to 7 years and between 12 to 34 years presented mostly mild stuttering, subjects between 8 to 11 years presented mostly moderate stuttering. From the total of 56 individuals who were evaluated, 92.85\% presented AP disorders. The most common auditory processing disorders were supra-segmental and decoding. No statistical differences were found considering the results of the AP evaluation and the severity of stuttering for none of the age groups. Conclusion: the AP evaluation indicated deficits for most of the participants of all age groups, however no correlations were observed with the severity of stuttering.
\end{abstract}

Key Words: Stuttering; Auditory Perceptual Disorders; Hearing.

\section{Resumo}

Tema: a avaliação comportamental do processamento auditivo (PA) permite pesquisar os processos neuroaudiológicos envolvidos no processamento da fluência. Objetivo: descrever os resultados da avaliação comportamental do PA em indivíduos gagos e comparar o grau de alteração da desordem do PA com o grau de gravidade da gagueira. Métodos: 56 indivíduos, 49 do gênero masculino e 7 do gênero feminino, com idades entre 4 e 34 anos, encaminhados do ambulatório de avaliação fonoaudiológica da UNIFESP para avaliação comportamental do PA. Todos os pacientes foram submetidos à avaliação de audição, fala e linguagem. A disfluência foi classificada segundo o protocolo de Riley (1994), o qual prevê os seguintes graus de gravidade da gagueira: muito leve, leve, moderado, severo e muito severo. Os testes para avaliação do PA foram selecionados e analisados de acordo com a idade do paciente e a proposta de Pereira \& Schochat (1997). Resultados: observamos prevalência da gagueira de grau leve na faixa etária de 4-7 anos e 12-34 anos de idade, e moderada nos indivíduos de 8-11 anos de idade. Dos 56 indivíduos avaliados $92,85 \%$ apresentaram alteração do PA. Os processos gnósicos mais prejudicados foram não verbal e decodificação. Não foram observadas diferenças estatisticamente significantes considerando os resultados da avaliação do processamento auditivo e o grau de gravidade da gagueira em nenhuma das faixas etárias avaliadas. Conclusões: a avaliação do PA mostrou-se comprometida em grande parte da amostra em todas as faixas etárias estudadas sem no entanto, correlação com o grau de gravidade da gagueira.

Palavras-Chave: Gagueira; Transtornos da Percepção Auditiva; Audição. 


\section{Introduction}

Auditory processing (AP) refers to a series of processes that involve the analysis and interpretation of sound stimuli. AP can be defined as a series of mental operations that individuals perform to process information received through their sense of hearing and depends upon an innate biological capability as well as experience in the acoustic environment (1).

Auditory processing disorder is the total or partial loss of function in the analysis of auditory images.

Verbal fluency can be defined as the continuous, smooth flow of speech stemming from the harmonic integration among the neural processes involved in language and motor skills (2).

The perception and production of speech are related events, in which the appreciation of the frequency, intensity and duration of sounds serves as the constructive foundation of hearing and language. The production of unintelligible speech depends largely on skill in processing the paradigms of the acoustic spectrum and the prosody of the speaker (3).

Genetic and environmental aspects can influence the development of stuttering and family predisposition can affect the fluency of individuals regarding the temporal capacity for speech (4-5). Gender also appears as a relevant factor, as a number of studies have demonstrated a higher prevalence of stuttering among males (6-8). However, for the assessment of auditory processing disorder, gender appears to only have minimal consequences (9).

The neuroaudiological processes involved in the processing of fluency can be investigated by means of an assessment of auditory processing. A correlation is known to exist between the processing of auditory information and its integration with visual pathways and an expressive language difficulty, which can be manifested as stuttering.(6) In the investigation of neurological processing in individuals with altered fluency, different authors raise the possibility of encountering small anatomical variations,(10-17) morphological differences,(18) hemispherical asymmetry (19) and/or difficulties in hearing, linguistic and motor aspects (20-22).

Neurophysiological processing of the fluency of speech depends upon the stability of the temporal coordination between the execution of motor skills and performance of cognitive processing (23). Thus, alterations in the fluency of speech stem from a momentary impediment of articulatory production (24).

A study investigating stuttering in young children by means of the dissociation of linguistic skill suggests that stuttering children exhibit a dissociation of speech and language skills, which could increase the interruptions in the fluency of speech (25).

Stuttering adults exhibit phonological processing that is similar to fluent individuals, but are more vulnerable to in increase in cognitive load and exhibit a considerable involvement of the right hemisphere in the delay of cognitive processes (26).

The correlation of findings on the assessment of auditory processing with findings on the assessment of language in individuals with altered speech fluency has been studied previously. Andrade et al. (27) found that $91 \%$ of individuals with dysfluency exhibited an alteration in auditory processing, in which the moderate alteration was the most prevalent, followed by mild alteration and no alteration (27).

Considering the correlation between auditory processing and dysfluency, the aims of the present study were:

. to describe the results of the assessment of auditory processing in stuttering individuals between 4 and 34 years of age;

. to compare the degree of auditory processing disorder with the degree of stuttering severity.

\section{Method}

The present project was analyzed and approved by the Research Ethics Committee of the Universidade Federal de São Paulo under n ${ }^{\circ}$ 0745/ 05 . A retrospective study was carried out though a survey of the medical files from 56 stuttering individuals assessed from 1999 to 2005 at the outpatient clinic for Hearing and Speech Assessment at the Sector of Human Communication Disorders of the Department of Hearing and Speech Therapy of the Universidade Federal de São Paulo and referred for the assessment of auditory processing.

All individuals were submitted to stutteringspecific hearing and speech assessments as well as basic hearing and auditory processing assessments. Patient files were analyzed considering age group, type and degree of speech dysfluency.

From the hearing and speech assessment, only the degree of stuttering severity was selected for 
the present study and was classified according to the Stuttering Severity Instrument for Children and Adults (SSI-3) in the following degrees: very mild, mild, moderate, severe and very severe.(28) This assessment tool considers the frequency and duration of interruptions in speech as well as the presence of concomitant physical aspects associated to the interruptions through an analysis of spontaneous speech and reading (only for individuals with reading skills). In this procedure, only atypical dysfluency is considered: repetition of syllables, repetition of sounds, prolonging, blocking, repetition of words (three repetitions or more).

The distribution of the sample regarding gender was 49 male individuals (87.5\%) and seven female individuals (12.5\%). Age ranged from 4 to 34 years, with a mean age of 12.35 years. The population was distributed into three age groups: 4-7 years $(\mathrm{N}=16)$, 8-11 years $(\mathrm{N}=16)$ and $12-34$ years $(\mathrm{N}=24)$.

Basic audiological assessment included patient history, meatoscopy, tonal audiometry, logoaudiometry, tympanometry and a study of contralateral acoustic reflexes. All individuals exhibited a satisfactory capacity for detecting and transmitting adequate sound through the tympanoossicular system.

Tests for the assessment of PA were selected and analyzed according to patient age and the method described by Pereira \& Schochat (1997).(29) Auditory processing disorders were classified according to auditory processing deficiencies.(1)

The following free field hearing tests were used (diotic task): sound localization test, memory test for verbal sounds in sequence, memory test for nonverbal sounds in sequence.

The other processing tests were carried out in a sound booth, using verbal and non-verbal stimuli recorded on a compact disc delivered through earphones coupled to a two-channel audiometer (Interacoustics AC33) calibrated in compliance with the ISO8253-1 norm (1989). The following tests were employed: pattern recognition of frequency and duration of pure tones, (30) pattern recognition of frequency and duration of musical flute tones, nonverbal dichotic test, vowel-consonant dichotic test, dichotic digit test, alternated disyllable dichotic test, identification of synthetic sentences with ipsilateral and contralateral competitive message, speech recognition percentage rate with recording, and speech test with white noise.

Data on auditory processing and degree of stuttering severity were recorded and statistically analyzed.

Spearman's Correlation test was used on nonparametric distributions, as this test is based on the ordination of two variables without any restriction to the distribution of values. The Correlation Coefficient test was used to test the correlation coefficient between variables. To complement the descriptive analysis, confidence intervals were determined for both average and proportion values.

The level of significance was set at $0.10(10 \%)$ in consideration of the small sample size. All confidence intervals were determined with $95 \%$ statistical confidence.

\section{Results}

Auditory processing was altered in 52 individuals (92.85\%). The individuals who exhibited adequate auditory processing in the tests were distributed in the 4-to-7-year age group (1 individual) and the >12-year age group (3 individuals). All individuals in the 8-to-11-year age group exhibited altered auditory processing.

Graphic 1 displays the degree of auditory processing disorder according to age group.

After analyzing the degree, auditory processing disorders were classified into nonverbal $(61.5 \%)$, decoding $(53.8 \%)$, organization $(53.8 \%)$ and coding $(26.9 \%)$, without considering the age variable.

In order to study the correlation between the processes involved and age group, these two variables were cross-referenced. Graphic 2 displays the results.

Table 1 displays the association and/or statistical dependence between the degree of stuttering severity and the degree of auditory processing disorder for each age group according to Spearman's Correlation. The results of the correlation are presented in percentages and $\mathrm{p}$ values. 


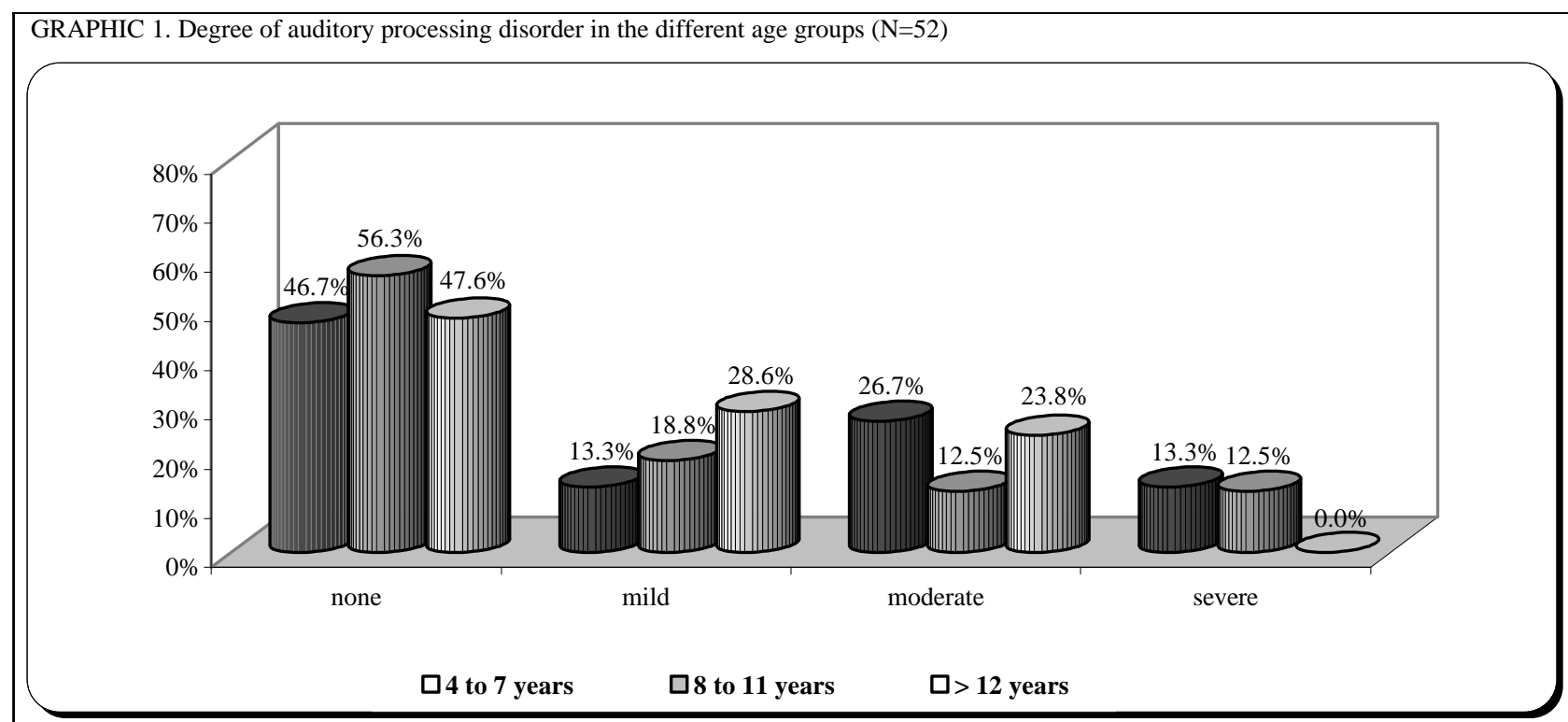

SRAPHIC 2. Alterations in auditory processes according to different age groups.

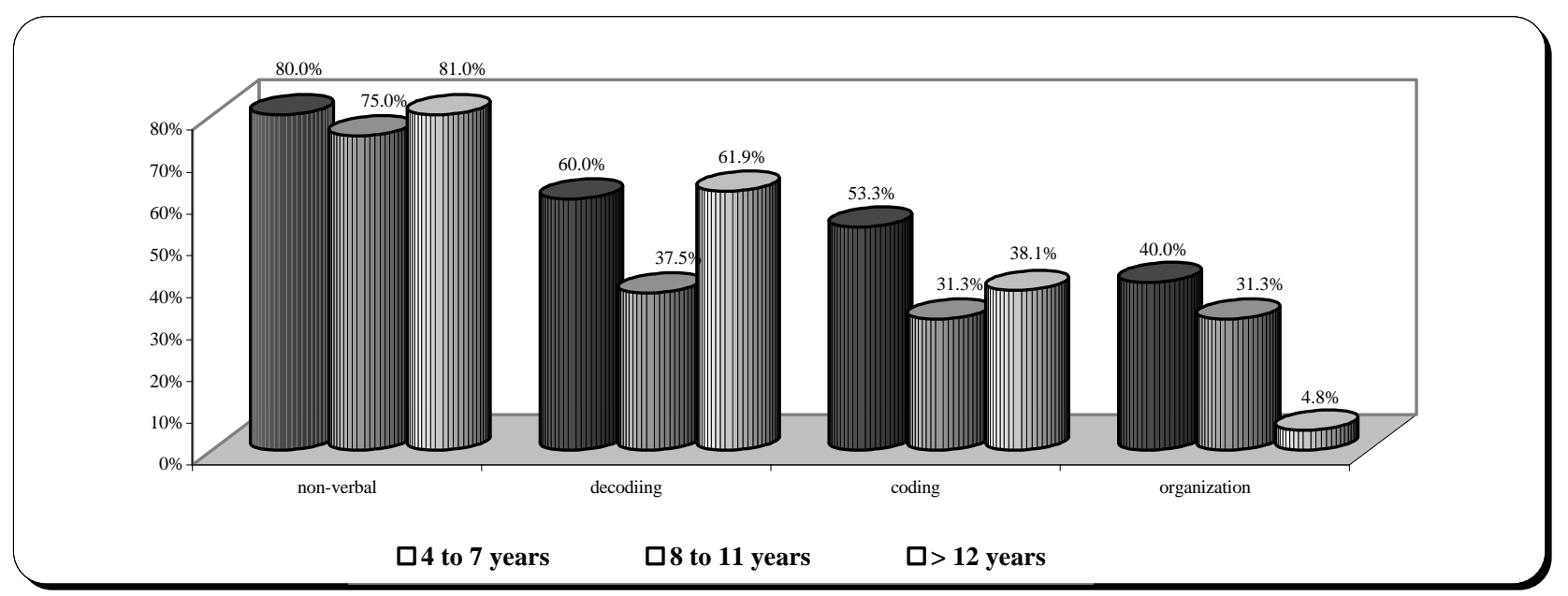

\begin{tabular}{|c|c|c|}
\hline \multicolumn{2}{|l}{ TABLE 1. Comparison between degree of auditory processing disorder and stuttering severity } & p value \\
\hline Degree of Stuttering Severity x PA & Correlation (\%) & $0.119^{\#}$ \\
\hline 4 to 7 years of age & $40, .6 \%$ & 0.234 \\
8 to 11 years of age & $31.6 \%$ & 0.682 \\
12 to 34 years of age & $-8.8 \%$ & \\
\hline
\end{tabular}

\# p-value approaching acceptance threshold and considered as tending toward significance. 


\section{Discussion}

Before commenting on the results, a few considerations will be made regarding the sample.

The sample was made up of 56 stuttering individuals, $87.5 \%$ of whom were male and $12.5 \%$ were female. The predominance of the male gender has been described in the literature. In the present study, there was a seven to one ratio of males to females. This result is similar to findings described the literature (6-8). The option was made not to separate the genders in the present study for the assessment of auditory processing, as this variable does not have a significant consequence in the assessment of auditory processing disorder, according to other studies in the literature (9).

Regarding age, the sample was made up of individuals between 4 and 34 years of age, with an average age of 12.35 years. The population was distributed in three age groups: 4 to 7 years, 8 to 11 years and $>12$ years. This division was performed according to the complexity and amount of special tests for the assessment of auditory processing, taking into account the neurological maturation process of the central auditory system.

PA alterations were found in 52 individuals $(92.85 \%)$. This result is similar to findings described in the literature $(6,27)$.

According to the quantitative analysis, although auditory processing was altered, approximately half of the population had PA disorder with no alteration in degree, regardless of the age group. The mild degree of dysfunction was the most prevalent (13.3 to $28.6 \%$ ). The moderate degree of alteration was more prevalent $(26.7 \%)$ only in the 4-to-7-year-old age group. These results are similar to another study that found a higher prevalence of the moderate degree of alteration, followed by the mild degree and no alteration in degree among individuals with complaints of an alteration in speech fluency (27).

In the analysis of the results of the special tests, only the dichotic digit test, alternating disyllable dichotic test and speech with white noise test provided us with the classification of the degree of auditory processing disorder. Thus, when any other test presented an alteration, we concluded that there was auditory processing disorder with no alteration in degree.

The mild category indicates dysfunction in nonauditory areas. The prevalence of mild PA disorder may be related to morphological differences in the cerebral cortex of stuttering adults in the prefrontal, motor-sensory and speech-language areas (18).
Regarding the auditory processing disorder categories, non-verbal auditory processing was highest among the sample studied, followed by the decoding, coding and organization processes. The involvement of two or more processes was observed in most of the individuals. These results are similar to findings described in the literature $(6,27)$.

The non-verbal auditory processing category is related to alterations in the temporal pattern test or the recognition of non-verbal sounds in dichotic hearing. This alteration may be attributed to a difficulty in acquiring or storing pieces of information that follow one another in time and may interfere with tonicity aspects of the language, which may cause the non-comprehension of a discourse due to prosody difficulties (1).

The predominance of the non-verbal auditory processing category may be explained by the fact that stuttering individuals either do not have hemispheric dominance for speech or have bilateral dominance $(19,25-26)$, have anatomic cerebral abnormalities, temporal lobe asymmetry and other anatomic peculiarities when compared to fluent individuals (10-17), have periodic irregularities in the temporalization of the movements of speech or alterations in temporal motor and sensory patterns (20-22).

The decoding and coding categories may respectively be associated to the acquisition of information from the phonemes of the language and the rules of meaning of the language, syntactic memory, semantic memory and phonological memory (1).

Alterations in these categories may be attributed to the fact that stuttering individuals have a momentary impediment to the articulatory production determined by the linguistic levels responsible for the elaboration of the utterance or speech production, in which there is difficulty in retrieving and sending the phonetic plan to the motor command (24).

Furthermore, linguistic skills and language resources may also interfere in the results of the auditory processing assessment. Although it was not the objective of the present study, most of the individuals either complained of or exhibited other language alterations beyond dysfluency.

There was no statistically significant association between the degree of stuttering severity and the degree of PA disorder for any of the age groups studied. This result corroborates 
findings described in the literature (27).

Nonetheless, a tendency toward significance was observed in the 4-to-7-year-old age group regarding this association, as the $\mathrm{p}$ value came close to the acceptance threshold. This tendency may be explained by two reasons: previously conducted research used stuttering children eight years of age or older as the study group and/or neurological maturity may have affected the auditory processing tests.

Even with procedures available for the evaluation of children starting at four years of age, this age group is affected by neurological maturation. Thus, the interpretation of the results the auditory processing assessment in small children must be made with caution, seeking to establish correlations with aspects of the history and behavior of the child in order to avoid false positive results. The correlation between the degree of PA disorder and stuttering should be further investigated in future studies.

The assessment of auditory processing is a useful complement to hearing and speech assessments. It is known that there is a correlation

\section{References}

1. Pereira LD. Sistema auditivo e desenvolvimento das habilidades auditivas. In: Ferreira LP, Béfi-Lopes D, Limongi SCO. Tratado de Fonoaudiologia. São Paulo: Roca; 2004. p. 547-52.

2. Andrade CRF, Juste F. Aplicação de um teste americano de severidade de gagueira (SSI) em crianças fluentes falantes do português brasileiro. Pró-Fono Rev. Atual. Cient. 2001;13(2):177-80

3. Pereira LD, Navas ALGP, Santos MTM. Processamento auditivo: uma abordagem de associação entre a audição e a linguagem. In: Santos MTM, Navas ALGP. Distúrbios de leitura e escrita: teoria e prática. Barueri: Manole; 2002. p. 75-95

4. Andrade CRF. História natural da gagueira-estudo II: sistema miofuncional oral e funções. Pró-Fono Rev. Atual Cient. 2002;14(3):361-70.

5. Andrade CRF. História natural da gagueira-estudo I: perfil da fluência. Pró-Fono Rev. Atual Cient. 2002;14(3):35160 .

6. Schiefer AM, Barbosa LMG, Pereira LD. Considerações preliminares entre uma possível correlação entre gagueira e os aspectos lingüísticos e auditivos. Pró-Fono Rev. Atual Cient. 1999;11(1):37-31.

7. Arcuri CF, Ishii C, Schiefer AM, Pereira LD. Fatores de risco auditivo em indivíduos gagos. Fono Atual. 2004;28(7):4-10. between auditory processing skills and speech fluency. Considering the high prevalence of PA alterations in stuttering individuals, it is of interest to include an auditory processing assessment in the specific evaluation of stuttering and use strategies in hearing and speech therapy that seek to improve the auditory processing skills of these individuals.

\section{Conclusions}

Following a critical analysis of the results from the assessment of auditory processing in stuttering individuals, we conclude that:

. auditory processing proved compromised in a large part of the sample in all the age groups studied, with no alteration in degree;

. the non-verbal hearing process was the most prevalent type of auditory processing disorder in the population studied;

. the degree of auditory processing disorder did not prove to have a significant correlation to the degree of stuttering severity in any of the age groups studied.

8. Faria AA, Ferriolo BHVM. Perfil dos sujeitos gagos do projeto em fluência da fala da Universidade de Ribeirão Preto. Fono Atual. 2005;34(8):58-64.

9. Pereira LD, Ortiz KZ. Desordem do processamento auditivo central e distúrbios da produção fonoarticulatória. In: Lichtig I, Carvallo RMM. Audição abordagens atuais. Carapicuíba: Pró-Fono; 1997. p. 173-86.

10. De Nil LF, Kroll RM, Lafaille SJ, Houle S. A positron emission tomography study of short- and long-term treatment effects on functional brain activation in adults who stutter. J Fluency Disord. 2003;28(4):357-79.

11. Foundas AL, Corey DM, Angeles V, Bollich AM, Crabtree-Hartman E, Heilman KM. Atypical cerebral laterality in adults with persistent developmental stuttering. Neurology. 2003;61:1378-85.

12. Foundas AL, Bollich AM, Feldman J, Corey DM, Hurley M, Lemen LC, Heilman KM. Aberrant auditory processing and atypical planum temporale in developmental stuttering. Neurology. 2004;63(9):1640-6.

13. Ingham RJ, Fox PT, Ingham JC, Xiong J, Zamarripa F, Hardies LJ, Lancaster JL. Brain correlates of stuttering and syllable production: gender comparison and replication. J Speech Lang Hear Res. 2004;47(2):321-41.

14. Corbera S, Corral MJ, Escera C, Idiazábal MA. Abnormal speech sound representation in persistent developmental stuttering. Neurology. 2005;65(8):1246-52. 
15. Brown S, Ingham RJ, Ingham JC, Laird AR, Fox PT. Stuttered and fluent speech production: an ALE metaanalysis of functional neuroimaging studies. Hum Brain Mapp. 2005;25(1):105-17.

16. Neumann K, Preibisch C, Euler HA, Von Gudenberg AW, Lanfermann H, Gall V, Giraud AL. Cortical plasticity associated with stuttering therapy. J Fluency Disord. 2005;30(1):23-39

17. Mertz LB, Ostergaard JR. Neurological aspects of stuttering. Ugeskr Laeger. 2006;168(37):3109-13.

18. Jäncke L, Hänggi J, Steinmetz H. Morphological brain differences between adult stutterers and non-stutterers. BMC Neurol. 2004;4(1):23.

19. Ozge A, Toros F, Cömelekoglu U. The role of hemispheral asymmetry and regional activity of quantitative EEG in children with stuttering. Child Psychiatry Hum Dev. 2004; 34(4):269-80.

20. Bosshardt HG, Ballmer W, De Nil LF. Effects of category and rhyme decisions on sentence production. J Speech Lang Hear Res. 2002;45(5):844-58.

21. Andrade CRF. Abordagem neurolingüística e motora da gagueira. In: Ferreira LP, Béfi-Lopes D, Limongi SCO. Tratado de Fonoaudiologia. São Paulo: Roca; 2004. p. 1001-16.

22. Biermann-Ruben K, Salmelin R, Schnitzler A. Right rolandic activation during speech perception in stutterers: a MEG study. Neuroimage. 2005;25(3):793-801.
23. Andrade CRF, Cervane LM, Sassi FC. Relationship between the stuttering severity index and speech rate. São Paulo Med J. 2003;121(2):81-4.

24. Pereira MMB, Ferrante C, Cohen C, Carvalho GGT. Análise da duração de consoantes na fala fluente de gagos. Rev Soc Bras Fonoaudiol. 2003;8(2):14-8.

25. Anderson JD, Pellowski MW, Conture EG. Childhood stuttering and dissociations across linguistic domains. J Fluency Disord. 2005;30(3):219-53.

26. Weber-Fox C, Spencer MCR, Smith JESA. Phonologic processing in adults who stutter: electrophysiological and behavioral evidence. J Speech Lang Hear Res. 2004;47:1244-58.

27. Andrade AN, Gil D, Schiefer AM, Pereira LD. Avaliação do processamento auditivo em indivíduos com queixa de disfluência. In: $20^{\circ}$ Encontro Internacional de Audiologia; 2005; Bauru. Anais. Bauru: $20^{\circ}$ Encontro Internacional de Audiologia. Bauru; 2005.

28. Riley GD. Stuttering severity instrument for children and adults-SSI-3. $3^{\mathrm{a}}$ ed. Austin: Texas; 1994.

29. Pereira LD, Schochat E. Processamento auditivo central: manual de avaliação. $1^{a}$ ed. São Paulo: Lovise; 1997.

30. Pinheiro ML, Musiek FE. Frequency patterns in cochlear, brainstem and cerebral lesions. Audiology. 1987;26:79-88. 